//ejurnal.pps.ung.ac.id/index.php/AKSARA/index

\title{
Meningkatkan Hasil Belajar Siswa Pada Mata Pelajaran PKN Melalui Metode Bermain Peran
}

\author{
Ratna Ibrahim \\ Guru SDN 07 Duhiadaa \\ ratnaibrahim@gmail.com
}

\begin{abstract}
Abstrak
Masalah dalam penelitian ini yaitu rendahnya hasil belajar siswa kelas IV SDN 07 Duhiadaa. Rumusan masalah yang diajukan yaitu apakah dengan menggunakan metode bermain peran dapat meningkatkan hasil belajar siswa di kelas IV SDN 07 Duhiadaa. Jenis penelitian ini adalah penelitian tindakan kelas yang dilaksanakan dalam 2 siklus dengan menggunakan desain penelitian model Kemis dan Mc Taggart. Adapun tahapan dalam penelitian ini meliputi tahap perencanaan, pelaksanaan tindakan, observasi, dan refleksi. Data yang diperoleh dalam penelitian ini meliputi hasil observasi aktivitas guru, dan lembar observasi aktivitas siswa. Subjek penelitian ini adalah siswa kelas IV SDN 07 Duhiadaa yang berjumlah 23 orang. Tes hasil tindakan siklus I diperoleh persentase kentuntasan klasikal sebesar 56,52\%, persentase daya serap klasikal 62,39\%. Pada siklus II hasil tes tindakan meningkat. Siklus II diperoleh persentase ketuntasan klasikal sebesar 91,30\%, persentase daya serap klasikal sebesar 80,21\%. Berdasarkan hasil tes dapat disimpulkan bahwa dengan menggunakan metode bermain peran dapat meningkatkan hasil belajar siswa kelas IV SDN 07 Duhiadaa
\end{abstract}

Kata Kunci: Hasil Belajar, Metode Bermain Peran

\section{PENDAHULUAN}

Guru adalah ujung tombak dalam mencerdaskan kehidupan bangsa dan pemberi pelajaran, sehingga dituntut untuk membuat murid mampu memahami pelajaran yang diajarkan baik yang mudah maupun pelajaran yang dianggap sulit. Untuk itu seorang guru dituntut mampu menerapkan model yang dianggap bisa memberikan nilai lebih dan dengan mudah dapat meningkatkan hasil belajar murid pada setiap mata pelajaran, khususnya pada pelajaran PKn.

Pendidikan kewarganegaraan (PKn) merupakan salah satu mata pelajaran yang diajarkan di jenjang pendidikan SD. Selaku guru SD dalam setiap pembelajaran dituntut menggunakan pendekatan, strategi dan metode pembelajaran yang dapat memudahkan murid memahami materi yang diajarkannya, namun masih sering terdengar keluhan dari para guru di lapangan tentang materi pelajaran PKn yang terlalu banyak dan keluhan kekurangan waktu untuk mengajarkan semua materi.

Menurut pengamatan penulis di dalam pelaksanaan pembelajaran PKn, khususnya di kelas IV SDN 07 Duhiadaa, penggunaan model pembelajaran yang bervariatif masih belum maksimal diterapkan dan guru masih cenderung menggunakan metode konvensional pada setiap pembelajaran yang dilakukannya. Hal ini mungkin disebabkan kurangnya penguasaan guru terhadap model - model pembelajaran yang ada. Situasi lain terlihat dalam kelas saat proses belajar mengajar yaitu sebagian murid yang memiliki kesulitan dalam belajar tidak mau terbuka dan tidak berani mengungkapkan kesulitan pada guru karena takut dianggap bodoh. Sehingga siswa kurang aktif dalam mengikuti kegiatan belajar. Yang ditandai ini siswa tersebut tidak mengumpulkan Pekerjaan Rumah (PR) dan tidak menjawab pertanyaan test awal dengan benar. Menurut siswa yang tidak mengerjakan pekerjaan rumahnya tugas - tugas yang diberikan oleh guru terlalu sulit. Karena ia mengalami kesulitan dalam menyelesaikan pekerjaan rumah (PR) yang diberikan maka ia merasa enggan untuk belajar dan tidak 
termotivasi untuk belajar. Hal ini akan berdampak pada hasil belajar siswa tidak maksimal seperti apa yang diharapkan.

Berdasarkan uraian diatas jelas bahwa ketidaksiapan siswa dalam belajar disebabkan oleh kurangnya motivasi siswa yang berawal dan ketidakmampuannya menyelesaikan soal soal tes baik tes yang diberikan pada akhir pembelajaran maupun tugas - tugas rumah yang diberikan guru. Hal ini memberi gambaran bahwa nilai rata - rata siswa kelas IV SDN 07 Duhiadaa, ternyata masih banyak siswa yang mengalami kesulitan dalam mengikuti materi yang sedang diajarkan dan lebih khusus pada kondisi pembelajaran mata pelajaran PKn.

Oleh karena itu, penulis mengambil satu kesimpulan bahwa pembelajaran PKn di kelas IV SDN 07 Duhiadaa masih sangat jauh tingkat keberhasilannya, maka dari itu penulis memilih salah satu metode belajar, yaitu metode bermain peran, yang diharapkan dapat meningkatkan hasil belajar siswa pada mata pelajaran PKn. Sehingga penulis memilih judul penelitian, "Meningkatkan Hasil Belajar Siswa Pada Mata Pelajaran Pkn Melalui Metode Bermain Peran Di Kelas IV SDN 07 Duhiadaa"

\section{KAJIAN TEORI}

\section{Hasil Belajar}

Menurut Hulgard dan Bower (dalam Purwanto 1998: 17) dikemukakan bahwa "belajar berhubungan dengan perubahan tingkah laku seseorang terhadap sesuatu situasi tertentu yang disebabkan oleh pengalamannya yang berulang - ulang dalam situasi itu, dimana perubahan tingkah laku itu tidak dapat dijelaskan atau dasar kecenderungan respon pembawaan, kematangan, atau keadaan - keadaan sesaat seseorang (misalnya: kelelahan, pengaruh obat, dan sebagainya)".

Menurut Witherington dalam buku Educational Psychology yang dikutip oleh Purwanto (1998: 84) dinyatakan bahwa "belajar adalah suatu perubahan didalam kepribadian yang menyatakan diri sebagai sesuatu pola baru dari pada reaksi yang berupa kecakapan, sikap, kebiasaan, kepandaian, atau suatu pengertian".

Selanjutnya menurut Slameto (2003: 2) belajar adalah suatu proses usaha yang dilakukan seseorang untuk memperoleh suatu perubahan tingkah laku yang baru secara keseluruhan sebagai hasil pengalamannya sendiri dalam interaksi dengan lingkungan.

Dari pengertian belajar tersebut dapat disimpulkan bahwa belajar adalah suatu proses usaha yang dilakukan seseorang untuk memperoleh perubahan tingkah laku yang disebabkan oleh pengalamannya yang berulang - ulang dalam interaksi dengan lingkungannya sehingga terjadi suatu perubahan yang menyangkut berbagai aspek kepribadian baik fisik maupun psikis seperti : perubahan di dalam pengertian, pemecahan suatu masalah / berfikir, ketrampilan, kecakapan, kebiasaan, ataupun sikap.

Ada beberapa faktor yang perlu diperhatikan dalam proses pembelajaran, faktor - faktor tersebut sangat menentukan tingkat capaian hasil belajar siswa, guru harus mengenali faktor faktor yang mempengaruhi pembelajaran sehingga dalam proses pembelajaran guru mampu menggunakan berbagai teknik untuk pembelajaran guna meningkatkan hasil belajar siswa.

Adapun faktor - faktor yang mempengaruhi hasil belajar sebagai berikut :

\section{1) Faktor internal}

Sehubungan dengan faktor internal ini ada tingkat yang perlu dibahas yaitu : (Oemar Hamalik, 2001: 32).

a) Faktor jasmani, dalam faktor jasmaniah ini dapat dibagi menjadi dua yaitu faktor kesehatan dan faktor cacat tubuh.

b) Faktor psikologi, dalam faktor psikologis ini dapat berupa intelegensi, perhatian, bakat, minat, motivasi, kematangan dan kesiapan oleh peserta didik itu sendiri. 
c) Faktor kelelahan, Ada beberapa faktor kelelahan yang dapat mempengaruhi hasil belajar siswa antara lain dapat dibedakan menjadi dua macam, yaitu kelelahan jasmani dan kelelahan rohani.

Kelelahan jasmani terlihat dengan lemah lunglainya tubuh dan timbul kecenderungan untuk membaringkan tubuh. Kelelahan jasmani terjadi karena ada substansi sisa pembakaran di dalam tubuh, sehingga darah kurang lancar pada bagian tertentu.

Sedangkan kelelahan rohani dapat terus menerus karena memikirkan masalah yang berarti tanpa istirahat, mengerjakan sesuatu karena terpaksa, tidak sesuai dengan minat dan perhatian.

2) Faktor eksternal

Faktor ekstern yang berpengaruh terhadap prestasi belajar dapatlah dikelompokkan menjadi tiga faktor yaitu: (Oemar Hamalik, 2001: 34).

a) Faktor keluarga, faktor ini sangat berperan aktif bagi siswa dan dapat mempengaruhi dari keluarga antara lain: cara orang tua mendidik, relasi antara anggota keluarga, keadaan keluarga, pengertian orang tua, keadaan ekonomi keluarga, latar belakang kebudayaan dan suasana rumah.

b) Faktor sekolah, faktor ini dapat berupa cara guru mengajar, alat - alat pelajaran, kurikulum, waktu sekolah, interaksi guru dan murid, disiplin sekolah, dan media pendidikan.

c) Faktor masyarakat, faktor yang mempengaruhi terhadap prestasi belajar siswa antara lain teman bergaul, kegiatan lain di luar sekolah dan cara hidup di lingkungan masyarakatnya.

Dari uraian di atas maka kelelahan jasmani dan rohani dapat mempengaruhi prestasi belajar dan agar siswa belajar dengan baik haruslah menghindari jangan sampai terjadi kelelahan dalam belajarnya seperti lemah lunglainya tubuh. Sehingga perlu diusahakan kondisi yang bebas dari kelelahan rohani seperti memikirkan masalah yang berarti tanpa istirahat, mengerjakan sesuatu karena terpaksa tidak sesuai dengan minat dan perhatian. Ini semua besar sekali pengaruhnya terhadap pencapaian prestasi belajar siswa. Agar siswa selaku pelajar dengan baik harus tidak terjadi kelelahan fisik dan psikis.

Menurut Benyamin S. Bloom dkk (dalam Purwanto 1998: 91) membagi kawasan belajar menjadi tiga bagian yaitu kognitif, efektif dan psikomotorik.Tes hasil belajar dalam penelitan ini adalah tes hasil belajar kawasan ukuran kognitif dalam bentuk tertulis. Hasil belajar adalah kemampuan yang dicapai, dikerjakan, dilakukan.Hasil belajar adalah kemampuan yang dicapai siswa dalam mata pelajaran, baik kualitas maupun jumlah pelajaran siswa selama periode yang diberikan yang diukur dengan menggunakan tes yang telah distandarisasikan. Dalam kaitannya dengan hasil belajar, hasil belajar adalah kemampuan yang dicapai dari proses belajar yang dapat diketahui dari capaian ketika mengerjakan serangkaian tes hasil belajar.

Menurut Slameto (2003: 4) Hasil belajar adalah perubahan kemampuan yang meliputi kemampuan kognitif, afektif, psikomotor. Woodworth dan DG. Marquis (dalam Slameto 2003: 12) mendefinisikan hasil belajar adalah kemampuan aktual yang dapat diukur secara langsung dengan tes.

Dari pengertian - pengertian tersebut dapat disimpulkan bahwa hasil belajar adalah perubahan kemampuan aktual yang meliputi kemampuan kognitif, afektif, psikomotor, yang dapat diukur secara langsung dengan menggunakan alat ukur berupa tes.

\section{Pembelajaran PKn}

Menurut Soemantri (1967) Pendidikan Kewarganegaraan Negara (PKN) merupakan mata pelajaran sosial yang bertujuan untuk membentuk atau membina warga negara yang baik, yaitu warga negara yang tahu, mau dan mampu berbuat baik. Sedangkan PKn adalah pendidikan kewarganegaraan, yaitu pendidikan yang menyangkut status formal warga negara 
yang pada awalnya diatur dalam Undang - Undang No. 2 th. 1949. Undang - Undang ini berisi tentang diri kewarganegaraan, dan peraturan tentang naturalisasi atau pemerolehan status sebagai warga NegaraIndonesia.

Tujuan PKn adalah untuk membentuk watak atau karakteristik warga negara yang baik. Sedangkan tujuan pembelajaran mata pelajaran PKn, menurut Mulysa (2007) adalah untuk menjadikan siswa :

1) mampu berpikir secara kritis, rasional, dan kreatif dalam menanggapi persoalan hidup maupun isu kewarganegaraan di negaranya.

2) mau berpartisipasi dalam segala bidang kegiatan, secara aktif dan bertanggung jawab, sehingga bisa bertindak secara cerdas dalam semua kegiatan, dan

3) bisa berkembang secara positif dan demokratis, sehingga mampu hidup bersam dengan bangsa lain di dunia dan mampu berinteraksi, serta mampu memanfaatkan teknologi informasi dan komunikasi dengan baik.

Berdasarkan tujuan tersebut diatas, maka materi dalam pembelajaran PKn perlu diperjelas. Oleh karena itu, ruang lingkup PKn secara umum meliputi aspek - aspek sebagai berikut. (1) Pesatuan dan Kesatuan, (2) Norma Hukum dan Peraturan, (3) HAM, (4) Kebutuhan warga Negara, (5) Konstitusi Negara, (6) Kekuasaan Politik, (7) Kedudukan Pancasila, dan (8) Globalisasi.

\section{Metode Bermain Peran}

Metode bermain peran berasumsi bahwa emosi dan ide - ide dapat diangkat ke taraf sadar untuk kemudian ditingkatkan melalui proses kelompok. Pemecahan tidak selalu datang dari orang tertentu, tetapi bisa saja muncul dari reaksi pengamat terhadap masalah yang sedang diperankan. Dengan demikian, para siswa dapat belajar dari pengalaman orang lain tentang cara memecahkan masalah yang pada gilirannya dapat dimanfaatkan untuk mengembangkan dirinya secara optimal. Dengan demikian, para siswa dapat belajar dari pengalaman orang lain tentang cara memecahkan masalah yang pada gilirannya dapat dimanfaatkan untuk mengembangkan dirinya secara optimal. Oleh sebab

itu, metode ini berusaha mengurangi peran guru yang teralu mendominasi pembelajaran dalam pendekatan tradisional.

Bermain peran akan berhasil apabila siswa menaruh minat dan memperhatikan masalah yang diajukan guru. Memilih peran dalam pembelajaran, tahap ini siswa dan guru mendeskripsikan berbagai watak atau karakter, apa yang mereka suka, bagaimana mereka merasakan, dan apa yang harus mereka kerjakan, kemudian para siswa diberi kesempatan secara sukarela untuk menjadi pemeran. Jika para siswa tidak menyambut tawaran tersebut, guru dapat menunjuk salah seorang siswa yang pantas dan mampu memerankan posisi tertentu.

Metode bermain peran adalah berperan atau memainkan peranan dalam dramatisasi masalah sosial atau psikologis. Bermain peran adalah salah satu bentuk permainan pendidikan yang di gunakan untuk menjelaskan perasaan, sikap, tingkah laku dan nilai, dengan tujuan untuk menghayati perasaan, sudut pandangan dan cara berfikir orang lain (Depdikbud, 1964:171).

Melalui metode bermain peran siswa diajak untuk belajar memecahkan masalah pribadi, dengan bantuan kelompok sosial yang anggotanya teman -temannya sendiri. Dengan kata lain metode ini berupaya membantu individu melalui proses kelompok sosial. Melalui bermain peran, para siswa mencoba mengeksploitasi masalah - masalah hubungan antar manusia dengan cara memperagakannya. Hasilnya didiskusikan dalam kelas.

Menurut Shaftel (1967) mengemukakan sembilan tahap bermain peran yang dapat dijadikan pedoman dalam pembelajaran: (1) menghangatkan suasana dan memotivasi siswa, 
(2) memilih partisipan / peran, (3) menyusun tahap - tahap peran, (4) menyiapkan pengamat, (5) pemeranan, (6) diskusi dan evaluasi, (7) pemeranan ulang, (8) diskusi dan evaluasi tahap dua, (9) membagi pengalaman dan mengambil kesimpulan.

\section{METODE PENELITIAN}

Pelaksanaan penelitian tindakan kelas ini mengikuti tahap tindakan yang bersiklus. Model penelitian ini mengacu pada modifikasi spiral yang dicantumkan Kemmis dan Mc Taggart (Depdiknas, 2005:6). Tiap siklus dilakukan beberapa tahap, yaitu 1) Perencanaan tindakan, 2) Pelaksanaan tindakan, 3) Observasi, dan 4) Refleksi.

Penelitian ini dilaksanakan di kelas IV SDN 07 Duhiadaa dengan subyek penelitian ini adalah seluruh siswa kelas IV berjumlah 23 orang siswa, terdiri dari 11 orang siswa laki - laki dan 12 orang siswa perempuan yang terdaftar pada tahun pelajaran 2015/2016.

Jenis data dalam penelitian ini yaitu data kuantitatif dan data kualitatif:

a) Data kuantitatif yaitu berupa kemampuan siswa menyelesaikan soal tentang materi yang diajarkan yang terdiri dari hasil tugas siswa, hasil tes awal dan tes akhir.

Data kuantitatif diperoleh dari tes akhir. Data tersebut kemudian diolah dan dinyatakan dalam bentuk persentase yang dihitung dengan menggunakan rumus sebagai berikut

Persentase daya serap individu

$$
\text { Daya Serap Individu }=\frac{\text { Skor Yang Diperoleh Siswa }}{\text { Skor Maksimum Soal }} \times 100 \%
$$

Siswa dikatakan tuntas belajar secara individu jika persentase daya serap individu $>65 \%$.

Ketuntasan Belajar secara Klasikal

$$
\text { Ketuntasan Belajar Klasikal }=\frac{\text { Skor Yang Diperoleh Siswa }}{\text { Skor Maksimum Soal }} \times 100 \%
$$

Suatu kelas dinyatakan tuntas belajar secara klasikal jika $>80 \%$ siswa yang telah tuntas.

b) Data kualitatif yaitu data hasil aktivitas guru dan siswa dalam pelajaran PKn serta data kesulitan siswa dalam memahami materi

Pengelolaan data kualitatif diambil dari data hasil aktivitas kegiatan guru dengan siswa yang diperoleh melalui lembar observasi dianalisis dan dinyatakan dalam bentuk persentase (Depdiknas, 2004: 37), yang dihitung dengan menggunakan rumus:

$$
\text { Presentase Nilai Rata }- \text { rata }=\frac{\text { Jumlah Skor }}{\text { Skor Maksimum }} \times 100 \%
$$

$$
\begin{array}{ll}
85 \%<\mathrm{NR}<10 \% & =\text { Sangat Baik } \\
75 \%<\mathrm{NR}<85 \% & =\text { Baik } \\
50 \%<\mathrm{NR}<75 \% & =\text { Cukup Baik } \\
30 \%<\mathrm{NR}<50 \% & =\text { kurang } \\
0 \%<\mathrm{NR}<30 \% & =\text { Sangat Kurang }
\end{array}
$$

\section{HASIL PENELITIAN \\ Hasil Penelitian Siklus I}

Pada siklus I, rencana tindakan yang dilakukan untuk meningkatkan hasil belajar siswa adalah guru menyiapkan rencana pelaksanaan pembelajaran (RPP) pada mata pelajaran Pkn, guru melakukan pengamatan terhadap aktivitas guru dan siswa selama pembelajaran berlangsung, guru menyiapkan lembar observasi aktivitas guru dan siswa, guru menyiapkan lembar kerja siswa materi melalui penerapan metode Bermain Peran, guru menyiapkan evaluasi akhir. 
Observasi terhadap aktivitas siswa dan guru dilakukan pada saat kegiatan pembelajaran berlangsung. Guru yang ditunjuk sebagai mitra bertindak sebagai observasi untuk mengamati aktivitas siswa dan guru menggunakan lembar observasi yang telah disediakan

Hasil yang diperoleh terlihat secara umum aspek yang diamati mengindikasikan bahwa aktivitas siswa dalam pembelajaran sudah masuk dalam kategori cukup dengan skor sebesar 33 dari skor maksimal 48 dan presentase yang diperoleh 68,7\%, maka dari hasil tersebut masuk dalam kriteria cukup. Hal ini dikarenakan siswa masih dalam tahap penyesuaian dengan temannya. Meskipun demikian terdapat beberapa siswa mewakili temannya untuk menjawab pertanyaan dari guru dan dari teman sendiri dengan cukup baik. Hasil observasi guru menunjukkan pada siklus I, skor yang diperoleh sebesar 29 dari skor maksimal 40, dengan rata - rata 72,5\%. Dengan demikian, hasil observasi aktivitas guru pada pertemuan pertama masuk dalam kategori cukup. Hal ini menunjukkan bahwa penugasan guru dalam menerapkan metode bermain peran pada mata pelajaran PKn di Kelas IV sudah baik.

Setelah pelaksanaan tindakan siklus I yang dilakukan dengan alokasi waktu 2 × 35 menit maka kegiatan selanjutnya adalah memberikan tes akhir. Tes ini berupa tes tertulis. Hasil tes yang diperoleh pada siklus I, nilai rata - rata hasil belajar siswa yang diperoleh 62,39\%. Dari 23 orang siswa hanya 13 orang yang memperoleh ketuntasan secara individu sehingga presentase

ketuntasan klasikal mencapai 56,52\%.

Pada tindakan siklus I dianggap belum berhasil sebab masih ada kelemahan - kelemahan yang perlu diperbaiki di antaranya siswa belum mampu memahami dan mengkaji materi dengan baik, siswa belum mampu mengerjakan tugas dari guru dengan baik sehingga hasil belajar yang diperoleh sangat rendah. Selain itu, guru menyampaikan materi terlalu terburu buru sehingga siswa merasa kurang paham dan guru kurang memberikan penghargaan kepada siswa.

Berdasarkan hasil analisis data tersebut, dapat disimpulkan bahwa pelaksanaan tindakan kelas dengan menerapkan metode Bermain Peran belum berhasil sehingga perlu dilakukan kembali penelitian pada siklus II.

\section{Hasil Penelitian Siklus II}

Berdasarkan hasil tindakan kelas pada siklus I, maka disusun perencanaan tindakan untuk siklus II dengan memperhatikan yang terjadi pada siklus I. Rencana tindakan yang dilakukan untuk meningkatkan hasil belajar siswa pada siklus II adalah guru menyiapkan rencana pelaksanaan pembelajaran (RPP) pada mata pelajaran Pkn, guru menyiapkan lembar pengamatan siswa dan guru yang akan digunakan pada saat berlangsungnya kegiatan pembelajan dikelas, dan guru membuat tes evaluasi akhir tindakan

Hasil observasi untuk siswa pada siklus II, menunjukkan adanya peningkatan pada aktivitas siswa dengan jumlah sebesar 42 dengan skor maksimal 36 sehingga dicapai presentase 91,6\% dengan kriteria sangat baik. Pembelajaran pada siklus II siswa sudah dapat memahami materi yang dibahas. Kegiatan Bermain Peran dikelas juga sudah ada peningkatan yang sangat baik. Pada tindakan siklus II, terjadi peningkatan yang sangat baik hampir seluruh aspek yang diamati, terutama menyangkut keaktifan murid dalam melakukan diskusi dan keantusiasan siswa dalam melakukan Bermain Peran. Hasil observasi aktivitas guru pada siklus II, terlihat adanya peningkatan yang cukup baik dibeberapa aspek yang diamati, seperti aspek dalam menyajikan informasi kepada murid bagaimana lewat bahan bacaan, guru menjelaskan kepada murid bagaimana mengerjakan tugas, guru memberikan kesempatan masing - masing murid untuk bertanya dan menjawab pertanyaan dari guru dan dari teman - temannya dan aspek guru dalam memberikan penghargaan kepada murid yang aktif dalam bermain peran. Hasil 
observasi diperoleh skor 35 dengan skor maksimal 35 sehingga dicapai presentase 87,5\%. Dengan demikian kriteria yang ditetapkan dalam penelitian tindakan kelas telah tecapai yaitu $75 \%<\mathrm{NR} \leq 100 \%$ yang masuk dalam kriteria sangat baik.

Berdasarkan hasil tes diketahui bahwa hasil tes yang diperoleh pada siklus II yakni dengan skor tertinggi 100, skor terendah 45 dan skor rata - rata yang diperoleh $80,21 \%$. Dari 23 siswa yang mengikuti tes yang tuntas belajar yakni 21 siswa dengan presentase ketuntasan 91,30\%. Berdasarkan hasil analisis data tersebut, dapat disimpulkan bahwa pemberian tindakan kelas dengan menerapkan metode bermain peran secara efektif dan efisien tidak perlu dilanjutkan ke siklus berikutnya. Dengan demikian, pembelajaran dengan menerapkan metode bermain peran dinyatakan tuntas dan mencapai target yang telah ditetapkan yakni minimal 80\%

\section{PEMBAHASAN}

Hasil belajar siswa merupakan nilai ranah kognitif yang diperoleh siswa berupa nilai hasil tes dengan pada siswa Kelas IV SDN 01 Duhiadaa. Nilai evaluasi tersebut diperoleh setelah dilaksanakannya pembelajaran dengan menerapkan metode bermain peran secara efektif dan efisien. Nilai terendah di kelas IV secara berturut - turut yaitu siswa yang mendapatkan nilai terendah adalah 2 orang pada siklus I dengan nilai 30. Dan nilai tertinggi dikelas IV SDN 07 Duhiadaa siklus I berjumlah 1 orang dengan nilai 100 dan pada siklus II nilai tertinggi ada 3 orang dengan nilai 100. Walaupun ada siswayang memperoleh nilai $\leq 6,5$ itu dikarenakan masih ada materi yang belum dipahaminya, dan berdasarkan pengamatan saat berlangsung metode bermain peran dikelas siswa masih mengalami kesulitan untuk memperaktekkannya. Hal ini dikarenakan belum terbiasa kegiatan bermain peran secara efektif dan efisien, padahal saat bermain peran berlangsung merupakan kesempatan yang baik bagi murid untuk menanyakan tentang sesuatu yang belum dipahaminya. Akibatnya, saat mengerjakan test siswa tersebut menjadi tidak bisa menjawab dengan baik. Namun banyak siswa yang telah berhasil mencapai hasil belajar secara individual. Indikator kinerja yang digunakan untuk menentukan tingkat keberhasilan pencapaian kompetensi dasar dalam penelitian ini adalah apabila siswa mencapai hasil belajar ranah kognitif secara individual $\geq 75 \%$ siswa telah mencapai ketuntasan belajar individual. Sehingga siswa dianggap ketuntasan belajarnya meningkat dan kompetensi dasar yang diinginkan tercapai serta kinerja guru dalam kegiatan pembelajaran meningkat.

Hasil belajar siswa pada siklus II telah mencapai indikator kinerja. Rata - rata kelas dan hasil belajar klasikal pada Kelas IV SDN 07 Duhiadaa telah sesuai dengan yang diharapkan. Pengalaman belajar yang menyenangkan dapat melekat dalam memori siswa periode waktu yang lebih lama, sehingga siswa akan lebih mudah meningkatnya kembali saat bermain peran dan mampu mengerjakan soal tes walaupun evaluasi tidak langsung dilaksanakan sesuai waktu pembelajaran

\section{KESIMPULAN}

Hasil tindakan siklus I menunjukkan nilai rata - rata hasil belajar siswa 62,39\% dan ketuntasan belajar klasikal mencapai 56,52\%. Hasil tindakan siklus II menunjukkan nilai rata - rata hasil belajar siswa 80,21\% dan ketuntasan belajar klasikal 91,30\%. Berdasarkan hasil di atas setiap tindakan menunjukkan peningkatan hasil belajar dan pada tindakan siklus II telah mencapai indikator kinerja yakni minimal 65 untuk nilai rata - rata hasil belajar dan minimal 80 untuk ketuntasan belajar klasik sehingga dapat disimpulkan bahwa upaya perbaikan pembelajaran dengan menggunakan metode bermain peran dapat meningkatkan hasil belajar siswa pada mata pelajaran PKn di kelas IV SDN 07 Duhiadaa 


\section{DAFTAR PUSTAKA}

Dahlan. (1984). Metode Bernain Peran. Jakarta : Gramedia

Depdikbud. (1964). Tujuan Pembelajaran. Jakarta : Dirjen Dikdasmen

Depdiknas. (2004). Prosedur Penelitian Tindakan Kelas. Jakarta : Dirjen Dikdasmen.

Hamalik, Oemar. (2001). Hasil Belajar. Jakarta: Gramedia.

Hasan. (1996). Proses Belajar. Jakarta : Rineka Cipta.

Mulyasa. (2007). Pendidikan Kewarganegaraan. Jakarta : Rineka Cipta

Purwanto, M.N. (1998). Metodologi Pengajaran di Sekolah Dasar. Jakarta : Rosda Jayaputra.

Shaftel. (1967). Tahap - tahap Bermain Peran. Bandung PT. Remaja Rosdakarya.

Slameto. (2003). Belajar dan Faktor - faktor yang Mempengaruhinya. Jakarta: Rineka Cipta.

Soemantri. (1967). Pendidikan Kewarganegaraan. Jakarta: Gramedia 